\section{A faltering start for Uno}

Tokyo

JAPAN's new prime minister Sosuke Uno, in his first policy speech before the Diet last week, pledged to "take positive initiatives" to solve global environmental problems, such as the greenhouse effect. $\mathrm{He}$ also called for greater development of science and technology and academic research and for the steady advance of nuclear power in Japan. But with the Recruit scandal still dominating Japanese politics, Uno may not be in power long enough to see his policies implemented.

Uno has experience in tackling inter-

$\stackrel{2}{8}$

IMAGE
UNAVAILABLE
FOR COPYRIGHT
REASONS

Premier Uno faces the media

national science and technology issues. In 1977 , as director general of the Science and Technology Agency, he succeeded in concluding an agreement with the United States allowing Japan to reprocess spent nuclear fuel.

In 1983, Uno was appointed head of the Ministry of International Trade and Industry. And a few days before his appointment as prime minister, Uno, then mental problems. for political reform.

Japan's foreign minister, reached agreement in Paris with US Secretary of Energy James Watkin for Japan and the United States to promote nuclear power as a "realistic approach" to global environ-

Uno is expected to put forward further Japanese proposals for the solution of global environmental problems at the upcoming seven-nation annual summit in July. He will also describe the organization of Japan's Human Frontier Science programme at next month's economic summit, provided national representatives of the seven participants can reach agreement on the agenda this week in Tokyo.

Last week, Uno also said that he intends to host an international conference on the global environment in Tokyo in September.

But while such international issues may help divert attention from domestic problems, Uno's prime task in the coming months will be to try and restore public faith in the ruling Liberal Democratic Party (LDP) before this summer's elections for the Upper House of the Diet. Support for the LDP has plunged to an all-time low in the wake of the Recruit scandal and Uno's policy speech was dominated by pledges

But Uno is already in trouble: last week the Sunday Mainichi magazine published revelations about his personal life from a "geisha" who claimed she had been his mistress. Questions were asked in the Diet, but Uno refused public comment. If the LDP loses its majority in the upper house, Uno could be forced to step down.

David Swinbanks JAPAN IN SPACE

\title{
Another victim for Recruit?
}

\section{Tokyo}

JAPAN's plans to participate in the building of the US space station have been seriously delayed by the Recruit scandal, the discovery that many members of the ruling Liberal Party had received financial benefits by being offered a chance to buy publicly-quoted shares at favourable prices. Although the scandal has led to the resignation of prime minister Takeshita and his replacement by Mr Sosuke Uno, the opposition parties are still not satisfied that full details have been uncovered.

One consequence is that a motion to approve the US-Japan inter-governmental agreement on the space station has been stalled in the Diet since April, as part of the opposition's boycott of Diet deliberations. As a result, the National Space Development Agency (NASDA) has not been able to begin on its part in the construction phase of the project.

The foreign-affairs committee of the lower house of the Diet is expected to debate the inter-governmental agreement this week. But it is uncertain whether the motion, which must also be debated in the upper house, will pass before the Diet closes for the summer recess on 22 June. Among other things, opposition parties are objecting to the possible military uses of the station.

Europe and Canada have already entered the construction phase after signing formal participation agreements last September. But even if the motion passes the Diet, Japanese contractors will be on a very tight schedule, according to Tatsuo Yonezawa of the international affairs division of NASDA. Funds for construction have been available in NASDA's budget since 1988 and contractors are itching to get started. But if the motion does not pass, "nobody knows" when construction can begin, Yonezawa says.

David Swinbanks
POST-ELECTION POLAND

Students' organization soft-pedals

\section{London}

Poland's Independent Student's Association (NZS) has called off all demonstrations and sit-ins until the autumn. Although the state and party authorities agreed, in the April "Round Table" accords, to recognize the NZS as a legal association, the Warsaw Provincial Court refused last month to register it, on the grounds that its statutes demanded the right to strike. This, the judge ruled, was contrary to the 1985 Higher Education Act, and also to the new law on associations, since - she said students are not employees and so, under existing legislation, have no right to strike.

After several days of sit-ins, strikes and street blockades throughout Poland, the students filed an appeal to the Supreme Court against the Provincial Court decision. The appeal is due to come up in October, conveniently coinciding with the opening of the next academic year. In the meantime, the students are putting considerable trust in Solidarity's landslide in the Parliamentary elections, and in the pledge of Solidarity's leader, Lech Walesa, that Deputies and Senators elected from the Solidarity list would treat the legalization of NZS as "a matter of urgency". Vera Rich TOXINS

\section{Neurolathyrism remains}

\section{a threat in India}

\section{New Delhi}

WHILE the 40,000 victims of the poison gas tragedy at Bhopal, capital of Madyha Pradesh, may hope to be rehabilitated following a settlement with Union Carbide, a far larger number of victims of poisoning must go without help elsewhere in the same state. These are the poor agricultural labourers who suffer from neurolathyrism, a crippling condition of the nervous system, caused by eating the foodgrain Lathyrus sativus.

Lathyrus sativus is a hardy crop that needs no irrigation, fertilizers or pesticides. Its seeds are rich in protein ( 28 per cent) but they also contain a neurotoxin called beta$\mathrm{N}$-oxalyl aminoalanine. Studies at the National Institute of Nutrition in Hyderabad 20 years ago showed that the toxin can cause permanent paralysis in monkeys.

Several thousand agricultural labourers in Madhya Pradesh have been living for decades on kesari dhal made with Lathyrus sativus and given to them by landlords as payment.

Agricultural scientists have tried for more than a decade to breed a toxin-free variety of Lathyrus sativus without success. The Agriculture Ministry claims, however, that the incidence of neurolathyrism is declining in Madhya Pradesh as rice and wheat become cheaper than Lathyrus sativus. K.S. Jayaraman 